\title{
Systemic Corticosteroid Therapy for Stevens-Johnson Syndrome and Toxic Epidermal Necrolysis in Vietnam: Clinical Evaluation and Analysis of Serum Cytokines
}

\author{
Thi Huyen Tran ${ }^{1,2 *}(\mathbb{D})$, Pham Thi Lan ${ }^{1,2} \mathbb{D}$, Tran Hau Khang ${ }^{1,2}$, Vu Huy Luong ${ }^{1,2}$ \\ ${ }^{1}$ Department of Dermatology and Venereology, Hanoi Medical University, Hanoi, Vietnam; ${ }^{2}$ Department of Outpatient, National \\ Hospital of Dermatology and Venereology, Hanoi, Vietnam
}

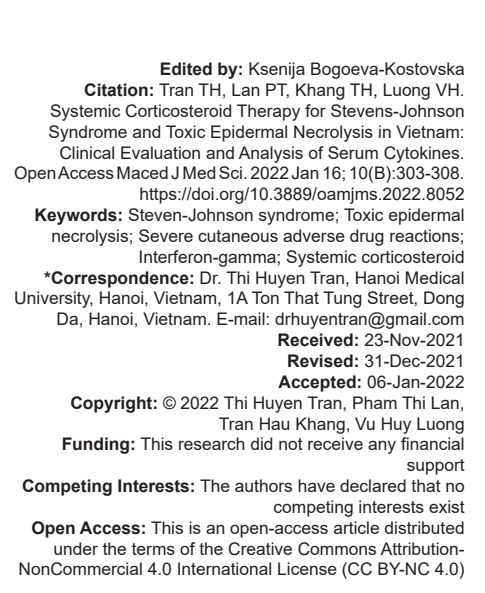

\section{Introduction}

Stevens-Johnson syndrome (SJS) and toxic epidermal necrolysis (TEN) are severe cutaneous adverse drug reactions [1]. Although their incidence is rare, around 2-3 per million per year their mortality rate can up to $5-30 \%$ [2], [3], [4]. These reactions are lifethreatening due to internal organ failures, disseminated skin detachment, and necrolysis [5]. Mucous membrane lesions are common in SJS/TEN with $97 \%$ of patients developed; oral involvement was observed in $93 \%$ of patients, ocular in $78 \%$, genital in $63 \%$, and all three sites in $66 \%$ [6]. The most common causative medicines inducing SJS/TEN are allopurinol, carbamazepine, sulfamethoxazole, and other antibiotics [7], [8], even traditional medicine [9]. SJS and TEN are categorized based on the percentage of epidermal detachment area: (i) SJS: $<10 \%$, (ii) TEN: $>30 \%$, iii) and overlapping SJS/TEN: $10-30 \%$ [1].

The pathogenesis of SJS/TEN is not fully understood, but there are some immunological and genetic factors that are believed to be involved [10], [11], [12], [13]. There is a strong association between $H L A-B * 15: 02$ and carbamazepine-induced SJS/ TEN [14], [15], HLA-B*58:01 and allopurinol-induced SJS/TEN [16], HLA-B*57:01 and abacavir-induced SJS/TEN [17]. Keratinocytes become extensive death because of apoptosis and/or necroptosis [18], [19]. This seems to be initiated by drug-specific cytotoxic $\mathrm{T}$ cell, amplified by natural killer cells. Some cytotoxic proteins, cytokines, and chemokines produced by these cells have involvement in the pathogenesis of SJS/TEN [19]. Among them, tumor necrosis factor-alpha (TNF- $\alpha$ ) [20], Fas ligand (FasL) [21], and perforin/granzyme B [22] were early suspected. Recent study demonstrated that granulysin is a key mediator for disseminated keratinocyte death in SJS/TEN [23].

The treatment of SJS/TEN is still controversial in which several studies showed variable results, including systemic corticosteroid [24], cyclosporine [25], [26], intravenous immunoglobulin (IVIG) [27], etanercept [28], thalidomide [29], and plasmapheresis [5]. Cytotoxic T cells and Fas-FasL, 
which play an essential role in the pathogenesis of SJS/TEN, are disabled by cyclosporine [26] and IVIG [27], [29], respectively. Hence, cyclosporine and IVIG are theoretically effective drugs in the management of SJS/TEN [5]. Corticosteroid has been used in the treatment of SJS/TEN for a long time. Proponents emphasize the important of high-dose corticosteroid indicated early in the disease development to block inflammation. On the other hand, systemic corticosteroid increases the risk of infection and sepsis [24]. In Vietnam, systemic corticosteroid has traditionally been used as the first choice to treat SJS/TEN due to its experience of use, being available and cheap cost. This study was conducted to evaluate clinically the efficacy of systemic corticosteroid and to analyze some related cytokines in the treatment of SJS/TEN.

\section{Methods}

\section{Study design and ethical clearance}

This open, pilot, and uncontrolled study had been approved by the Ethical Review Committee on Research Involving Human Subjects, Hanoi Medical University (Number 04NCS17, dated February 8, 2018). Written consent was obtained from all participants. It was conducted at the National Hospital of Dermatology and Venereology, in Hanoi, Vietnam, from October 2017 to September 2019.

\section{Patients}

In total, 32 patients with SJS/TEN were enrolled. The SJS/TEN patients had their vital signs, systemic symptoms, and the percentage of body surface area affected (skin detachment) examined. SJS and TEN were classified in accordance with BastujiGarin [1]. They were included if they met the following criteria: aged more than 17 years, admission $<10$ days after onset (that was defined as the day mucocutaneous or ocular lesions were first eroded or ulcerated) of SJS/TEN. Exclusion criteria were prior treatment with other immunosuppressive drugs (IVIG, cyclosporine, cyclophosphamide), history of osteoporosis or stomachache, uncontrolled diabetes mellitus, psychiatric disorders, human immunodeficiency virus positivity, and cases of multi-organ failure and sepsis.

\section{Therapy}

Systemic corticosteroid (methylprednisolone) was intravenously indicated from the $1^{\text {st }}$ day of hospitalization with the dose of $0.5-2.5 \mathrm{mg} / \mathrm{kg} / \mathrm{day}$ (calculated according to prednisolone dose), once daily. It was continued until the patients got re-epithelialization. No other immunosuppressant was administered.
Barrier nursing, topical treatment, ambient temperature of $30^{\circ} \mathrm{C}$, fluid and electrolyte balance, and high caloriecontaining diet were considered in each patient. Antibiotics were considered if strongly suspected or evident of bacterial infection or sepsis.

\section{Clinical evaluation}

The patients were evaluated clinically daily for the entire period of hospitalization. Efficacy of methylprednisolone was assessed by the average number of days of hospitalization, rate of re-epithelialization, the rate of in-hospital mortality and the tolerance to methylprednisolone. The onset in patients with SJS/TEN was defined as the day mucocutaneous or ocular lesions were first eroded or ulcerated. Re-epithelialization was defined as complete healing of the skin without any erosion.

\section{Analysis cytokines}

For 32 SJS/TEN patients, we took blood samples at two time points: (1) at the day of hospitalization, (2) at the day of re-epithelialization. All blood samples were left to coagulate at room temperature 10-20 min, then centrifuged in $20 \mathrm{~min}$ at a speed of 2000-3000 r.p.m, finally serum was taken and stored at $-80^{\circ} \mathrm{C}$ until proceeding the cytokine measurement. We measured serum interferon-gamma (IFN- $\gamma$ ), TNF- $\alpha$, interleukin (IL)-2, IL-4, IL-5, IL-13, IL-10 levels by using the fluorescence covalent microbead immunosorbent assay (ProcartaPlex Immunoassay Panels kit, Thermo Fisher Scientific, USA).

\section{Statistical analysis}

Data entry and analysis were conducted by using SPSS software version 16.0 (IBM, Armonk, NY, USA). The Wilcoxon tests were used to compare quantitative variables before and after the treatment. Differences were considered to be statistically significant at $p<0.05$.

\section{Results}

\section{Characteristics of the patients}

There were 32 patients with SJS/TEN (15 SJS patients, 17 TEN patients) participating in our study. Characteristics of patients with SJS/TEN are shown in Table 1. The mean age of patients was $48.8 \pm 13.9$, range $21-72$ years $(62.5 \%$ males; $37.5 \%$ females). The most common causative drugs of SJS/TEN were traditional medicine (18.8\%), allopurinol (18.8\%), and carbamazepine (12.5\%). There were 11 patients 
Table 1: Characteristics of patients with SJS/TEN

\begin{tabular}{|c|c|c|c|}
\hline Characteristics & SJS (n = 15) & $\operatorname{TEN}(\mathrm{n}=17)$ & SJS/TEN $(n=32)$ \\
\hline $\begin{array}{l}\text { Age, years } \\
\text { (Range) }\end{array}$ & $\begin{array}{l}43.9 \pm 14.4 \\
(21-72)\end{array}$ & $\begin{array}{l}53.2 \pm 12.3 \\
(30-69)\end{array}$ & $\begin{array}{l}48.8 \pm 13.9 \\
(21-72)\end{array}$ \\
\hline \multicolumn{4}{|l|}{ Sex, n (\%) } \\
\hline Male & $11(73.3)$ & $9(52.9)$ & $20(62.5)$ \\
\hline Female & $4(26.7)$ & $8(47.1)$ & $12(37.5)$ \\
\hline \multicolumn{4}{|l|}{ Causative drugs, $n(\%)$} \\
\hline Carbamazepine & $3(20)$ & $1(5.9)$ & $4(12.5)$ \\
\hline Allopurinol & $4(26.7)$ & $2(11.8)$ & $6(18.8)$ \\
\hline Traditional medicine & $1(6.7)$ & $5(29.4)$ & $6(18.8)$ \\
\hline Antibiotics & $1(6.7)$ & $1(5.9)$ & $2(6.2)$ \\
\hline $\begin{array}{l}\text { NSAIDs (diclofenac, } \\
\text { phenylbutazon) }\end{array}$ & $1(6.7)$ & $1(5.9)$ & $2(6.2)$ \\
\hline Thalidomide & $0(0)$ & $1(5.9)$ & $1(3.1)$ \\
\hline Unknown & $5(33.3)$ & $6(35.3)$ & $11(34.4)$ \\
\hline \multicolumn{4}{|c|}{ Taking systemic corticoid before hospitalization, $\mathrm{n}(\%)$} \\
\hline Yes & $5(33.3)$ & $9(52.9)$ & $14(43.8)$ \\
\hline No & 7 (46.7) & $7(41.2)$ & $14(43.8)$ \\
\hline Unknown & $3(20)$ & $1(5.9)$ & $4(12.5)$ \\
\hline Delay of administration & $3.7 \pm 1.3$ & $3.7 \pm 2.0$ & $3.7 \pm 1.7$ \\
\hline \multicolumn{4}{|c|}{ The mean dose of systemic corticosteroid (calculated according to prednisolone dose), } \\
\hline $\begin{array}{l}\mathrm{mg} / \mathrm{kg} / \mathrm{day} \\
\text { (Range) }\end{array}$ & $\begin{array}{l}1.4 \pm 0.5 \\
(0.7-2.4)\end{array}$ & $\begin{array}{l}1.8 \pm 0.4 \\
(0.8-2.5)\end{array}$ & $\begin{array}{l}1.6 \pm 0.5 \\
(0.7-2.5)\end{array}$ \\
\hline \multicolumn{4}{|c|}{ The time of re-epithelialization, } \\
\hline $\begin{array}{l}\text { Days } \\
\text { (Range) }\end{array}$ & $\begin{array}{l}13.1 \pm 3.8 \\
(9-23)\end{array}$ & $\begin{array}{l}18.4 \pm 4.1 \\
(11-31)\end{array}$ & $\begin{array}{l}15.9 \pm 4.8 \\
(9-31)\end{array}$ \\
\hline \multicolumn{4}{|c|}{ The time of hospitalization, } \\
\hline $\begin{array}{l}\text { Days } \\
\text { (Range) }\end{array}$ & $\begin{array}{l}10.9 \pm 4.4 \\
(5-21)\end{array}$ & $\begin{array}{l}20.4 \pm 5.1 \\
(11-30)\end{array}$ & $\begin{array}{l}15.9 \pm 6.7 \\
(5-30)\end{array}$ \\
\hline
\end{tabular}

$(34.4 \%)$ with unknown culprit drugs. Fourteen patients $(43.8 \%)$ were treated with systemic corticosteroid before being hospitalized. The time between the onset and the day of hospitalization was $5.9 \pm 2.8$ days

\section{Systemic corticosteroid treatment}

The mean dose of corticosteroid was $1.6 \mathrm{mg} / \mathrm{kg} /$ day (range $0.7-2.5 \mathrm{mg} / \mathrm{kg} /$ day). No patient was indicated with pulse methylprednisolone therapy. The mean time of re-epithelialization was 15.9 days (range 9-31 days), of hospitalization was 15.9 days (range 5-30 days), as shown in Table 1. There was no in-hospital mortality in this study. The common complications during the treatment with systemic corticosteroid were transient glycemia (40.6\%), decreasing blood potassium level $(21.9 \%)$, bronchitispneumonia (12.5\%), and candidiasis on the mouth $(9.4 \%)$, there was no patient with sepsis (Table 2).

Table 2: Complications of SJS/TEN patients treated with systemic corticosteroid $(n=32)$

\begin{tabular}{lll}
\hline Complications & $\mathrm{n}$ & $\%$ \\
\hline Transient glycemia & 13 & 40.6 \\
Decreasing blood potassium level & 7 & 21.9 \\
Bronchitis-pneumonia & 4 & 12.5 \\
Candidiasis on the mouth & 3 & 9.4 \\
Sepsis & 0 & 0 \\
\hline SJS. Stevens-Johnson syndrome TEN: Toxic epidermal necrolysis.
\end{tabular}

\section{The changes of cytokines}

At the day of re-epithelialization, serum concentrations of TNF- $\alpha$, IFN- $\gamma$, IL-2, IL-5, IL-13, and IL-10 were significantly lower than those at the day of hospitalization ( $p<0.05$ or $p<0.001$ ). Serum levels of IL-4 did not have significant differences between 2 time points $(p>0.05)$. The most significant changes were with serum TNF- $\alpha$ and IFN- $\gamma$ levels. These findings are shown in Figure 1.

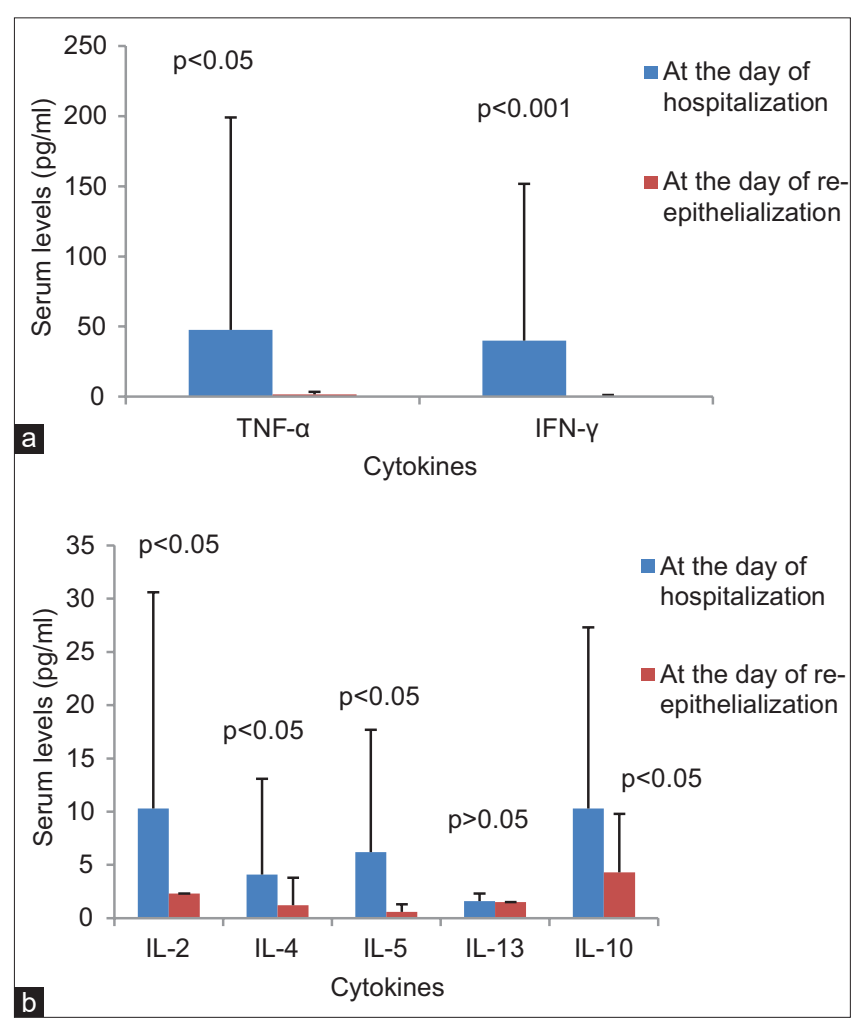

Figure 1: (a) Serum levels of tumour necrosis factor $\alpha$ and interferon $\gamma$, (b) Serum levels of interleukin (IL)-2, IL-4, IL-5, IL-13 and IL-10 at the day of hospitalization and at the day of re-epithelialization

\section{Discussion}

In this study, we evaluated the use of systemic corticosteroid as a primary treatment in 32 SJS/TEN patients who were managed in a single dermatology center. There were the following important results. First, we found that the use of systemic corticosteroid had possibly contributed to the survival of all patients. Second, the treatment was most often well tolerated despite having some side effects such as transient glycemia, decreasing blood potassium level, bronchitispneumonia, and candidiasis on the mouth, but not sepsis. Third, systemic corticosteroid decreased significantly serum levels of some proinflammatory and anti-inflammatory cytokines, especially with TNF- $\alpha$ and IFN- $\gamma$.

The precise action of corticosteroid in inflammatory diseases remains not well understood. They have pleomorphic immune-modulating effects through inhibition of numerous cytokines [30], [31]. The use of corticosteroids in SJS/TEN is controversial with various results. Retrospective analysis of the EuroSCAR data indicated a lower mortality in German patients (but not French patients) treated with corticosteroids compared with controls receiving supportive care alone [24]. Others studies showed that the observed mortality rate is lower than the predicted mortality rate that was estimated based on SCORTEN [32]. Corticosteroid therapy in SJS/TEN is carefully considered because of the possibility of 
delayed healing and the risk of infection [5]. However, short courses of high-dose corticosteroids in early SJS/ TEN have a good rational, as immune mechanisms are directly responsible for the cascade of events leading to apoptosis [32]. In the study by Kardaun and Jonkman, 12 patients received $100 \mathrm{mg}$ or $1.5 \mathrm{mg} / \mathrm{kg}$ of intravenous dexamethasone (a potent glucocorticoid, about 7 times as potent as the same dose of prednisolone) for 3 days and were reported to have a decreased mortality compared with SCORTEN [32]. Hirahara et al. presented a series of eight patients with SJS/TEN who received $1000 \mathrm{mg}$ of intravenous methylprednisolone on 3 consecutive days, followed by either a tapering course of oral prednisolone or a further 2 days of halfdose intravenous methylprednisolone. No patient died despite a SCORTEN-predicted mortality of 1.6 [31]. Our findings can support to the benefit of corticosteroid therapy in the survival of SJS/TEN patients.

The mean delay to the administration of using corticosteroid therapy in this study was 3.7 days (from the onset), the mean dose was $1.6 \mathrm{mg} / \mathrm{kg} /$ day prednisolone equivalent that lasted until re-epithelialization. It means that corticosteroid was given quite late and for too long during the process. This can explain the high rate of side-effects in this study, although they were transient (glycemia, decreasing blood potassium level). The general negative opinion of corticosteroid suggests that during the healing phase, corticosteroid may indeed impair wound healing and promote sepsis [32]. But we did not observe any SJS/TEN patient with sepsis. SCORTEN could not be measured because blood bicarbonate test was not available in the study settings. Hence, we did not calculate the predicted mortality number. Actually, there was no in-hospital mortality. This finding can be comparable with the result of other treatments in SJS/TEN, for example, cyclosporine, etanercept, or pulse methylprednisolone therapy.

In SJS/TEN, IFN- $\gamma$ has been reported to play a key role by initiating the cytotoxic activities [33], which is a shared mechanism connecting the involvement of TNF- $\alpha$ and FasL [20]. The apoptotic effects of IFN- $\gamma$ can also be explained by its transcriptional regulation of a variety of genes that are vital for apoptosis, such as TNF-a receptor, Fas/FasL, caspase-1, -4, and -8 [21], [34], [35], [36]. Finally, IFN- $\gamma$ contributes to the antigen processing and presentation and thus stimulates the cell-mediated immunity by upregulation of $\mathrm{MHC}$ molecules [37], [38], [39]. Activated T cells secrete large amounts of TNF- $\alpha$ and IFN- $\gamma$, which have the ability to induce inducible nitric oxide synthase expression and nitric oxide production by keratinocytes, resulting in FasF upregulation and Fas-mediated keratinocyte apoptosis [20]. Etanercept therapy would act by blocking this inflammatory pathway via TNF- $\alpha$ inhibition [28].

Cytokine receptors may be involved strongly in the recruitment of inflammatory cells in the lesion skin [33]. There was a sharp polarization towards a
$\mathrm{T}$ help (Th) 1 pattern in erythema multiforme, while the SJS/TEN lesions showed a mixed Th1/Th2 pattern [33]. In this study, both Th1-derived cytokines (TNF- $\alpha$, IFN- $\gamma$, IL-2) and Th2- derived cytokines (IL$5, \mathrm{IL}-13)$ decreased their serum levels at the day of re-epithelialization compared with those at the day of hospitalization. Hirahara et al. showed that at day 4 after methylprednisolone administration, mean levels of IFN$\gamma$, TNF- $\alpha$, IL-6, and IL-10 were decreased compared with pre-administration levels (day 0 ), but only changes in IFN- $\gamma$ and IL- 6 reached statistical significance. At day 19 , a significant reduction in the mean levels of IFN- $\gamma$, TNF- $\alpha$, and IL- 6 was observed compared with levels before administration of methylprednisolone [31]. In this study, the change of IFN- $\gamma$, TNF- $\alpha$, and IL-10 serum levels were consistent with those in Hirahara's study. The decrease in proinflammatory cytokine levels suggests that corticosteroid therapy may contribute to the survival of all SJS/TEN patients.

The present study is not large, lacks a control group and the predicted mortality number based on SCORTEN. However, it has some advantages because its results were evaluated with regard to not only the clinical progress but also the measurement of cytokine levels before and after treatment. All patients were seen by the same dermatologists at a single dermatology center.

\section{Conclusion}

The systemic corticosteroid is a good choice in the treatment of SJS/TEN. It can reduce serum levels of some important cytokines that help SJS/TEN patients with avoiding mortality. However, side effects and the time of using systemic corticosteroid should be concerned.

\section{References}

1. Bastuji-Garin S, Rzany B, Stern RS, Shear NH, Naldi L, Roujeau JC. Clinical classification of cases of toxic epidermal necrolysis, Stevens-Johnson syndrome, and erythema multiforme. Arch Dermatol. 1993;129(1):92-6. PMid:8420497

2. Schwartz RA, McDonough PH, Lee BW. Toxic epiderma necrolysis: Part I. Introduction, history, classification, clinical features, systemic manifestations, etiology, and immunopathogenesis. J Am Acad Dermatol. 2013;69(2):173. e1-13; quiz 185-6. https://doi.org/10.1016/j.jaad.2013.05.003 PMid:23866878

3. Su SC, Mockenhaupt M, Wolkenstein P, Dunant A, Le Gouvello S, Chen CB, et al. Interleukin-15 is associated with severity and mortality in stevens-johnson syndrome/toxic epidermal necrolysis. J Invest Dermatol. 2017;137(5):1065-73. 
https://doi.org/10.1016/j.jid.2016.11.034

\section{PMid:28011147}

4. Wolkenstein P, Latarjet J, Roujeau JC, Duguet C, Boudeau S, Vaillant $\mathrm{L}$, et al. Randomised comparison of thalidomide versus placebo in toxic epidermal necrolysis. Lancet Lond Engl. 1998;352(9140):1586-9. https://doi.org/10.1016/ S0140-6736(98)02197-7

PMid:9843104

5. Creamer D, Walsh SA, Dziewulski P, Exton LS, Lee HY, Dart JK, et al. U.K. guidelines for the management of StevensJohnson syndrome/toxic epidermal necrolysis in adults 2016. Br J Dermatol. 2016;174(6):1194-227. https://doi.org/10.1111/ bjd. 14530

PMid:27317286

6. Revuz J, Penso D, Roujeau JC, Guillaume JC, Payne CR, Wechsler $\mathrm{J}$, et al. Toxic epidermal necrolysis. Clinical findings and prognosis factors in 87 patients. Arch Dermatol. 1987:123(9):1160-5. https://doi.org/10.1001/ archderm.123.9.1160

PMid:3632000

7. Sassolas B, Haddad C, Mockenhaupt M, Dunant A, Liss Y, Bork K, et al. ALDEN, an algorithm for assessment of drug causality in Stevens-Johnson syndrome and toxic epidermal necrolysis: Comparison with case-control analysis. Clin Pharmacol Ther. 2010;88(1):60-8. https://doi.org/10.1038/clpt.2009.252 PMid:20375998

8. Chung WH, Wang CW, Dao RL. Severe cutaneous adverse drug reactions. J Dermatol. 2016;43(7):758-66. https://doi. org/10.1111/1346-8138.13430

PMid:27154258

9. Yang L, Shou YH, Li F, Zhu XH, Yang YS, Xu JH. Retrospective study of 213 cases of Stevens-Johnson syndrome and toxic epidermal necrolysis from China. Burns $\mathrm{J}$ Int Soc Burn Inj. 2020;46:959-69. https://doi.org/10.1016/j.burns.2019.10.008 PMid:31898979

10. Nassif A, Bensussan A, Dorothée G, Mami-Chouaib F, Bachot N, Bagot $M$, et al. Drug specific cytotoxic T-cells in the skin lesions of a patient with toxic epidermal necrolysis. J Invest Dermatol. 2002;118(4):728-33. https://doi. org/10.1046/j.1523-1747.2002.01622.x PMid:11918724

11. Nassif A, Bensussan A, Boumsell L, Deniaud A, Moslehi $H$, Wolkenstein $\mathrm{P}$, et al. Toxic epidermal necrolysis: Effector cells are drug-specific cytotoxic T cells. J Allergy Clin Immunol. 2004;114(5):1209-15. https://doi.org/10.1016/j.jaci.2004.07.047 PMid: 15536433

12. Fricke-Galindo I, LLerena A, López-López M. An update on HLA alleles associated with adverse drug reactions. Drug Metab Pers Ther. 2017;32(2):73-87. https://doi.org/10.1515/ dmpt-2016-0025

PMid:28315856

13. Chung $\mathrm{WH}$, Chang $\mathrm{WC}$, Lee $\mathrm{YS}$, Wu YY, Yang $\mathrm{CH}$, Ho HC, et al. Genetic variants associated with phenytoin-related severe cutaneous adverse reactions. JAMA. 2014;312(5):525-34 https://doi.org/10.1001/jama.2014.7859

PMid:25096692

14. Man CB, Kwan P, Baum L, Yu E, Lau KM, Cheng AS, et al. Association between HLA-B*1502 allele and antiepileptic drug-induced cutaneous reactions in Han Chinese. Epilepsia. 2007;48(5):1015-8. https://doi. org/10.1111/j.1528-1167.2007.01022.x PMid:17509004

15. Nguyen DV, Chu HC, Nguyen DV, Phan MH, Craig T, Baumgart K, et al. HLA-B*1502 and carbamazepine-induced severe cutaneous adverse drug reactions in Vietnamese.
Asia Pac Allergy. 2015;5(2):68-77. https://doi.org/10.5415/ apallergy.2015.5.2.68

PMid:25938071

16. Hung SI, Chung WH, Liou LB, Chu CC, Lin M, Huang HP et al. HLA-B*5801 allele as a genetic marker for severe cutaneous adverse reactions caused by allopurinol. Proc Natl Acad Sci U S A. 2005;102(11):4134-9. https://doi.org/10.1073/ pnas. 0409500102

PMid: 15743917

17. Mounzer K, Hsu R, Fusco JS, Brunet L, Henegar CE, Vannappagari $V$, et al. HLA-B*57:01 screening and hypersensitivity reaction to abacavir between 1999 and 2016 in the OPERA ${ }^{\circledast}$ observational database: A cohort study. AIDS Res Ther. 2019;16(1):1. https://doi.org/10.1186/s12981-019-0217-3 PMid:30651100

18. Saito N, Qiao H, Yanagi T, Shinkuma S, Nishimura K, Suto A, et al. An annexin A1-FPR1 interaction contributes to necroptosis of keratinocytes in severe cutaneous adverse drug reactions. Sci TransI Med. 2014;6(245):245ra95. https://doi.org/10.1126/ scitransImed.3008227

PMid:25031270

19. Chung WH, Hung SI. Genetic markers and danger signals in Stevens-Johnson syndrome and toxic epidermal necrolysis. Allergol Int. 2010;59(4):325-32. https://doi.org/10.2332/ allergolint.10-RAI-0261

PMid:20962567

20. Viard-Leveugle I, Gaide O, Jankovic D, Feldmeyer L, Kerl K, Pickard $\mathrm{C}$, et al. TNF- $\alpha$ and IFN- $\gamma$ are potential inducers of Fas-mediated keratinocyte apoptosis through activation of inducible nitric oxide synthase in toxic epidermal necrolysis. J Invest Dermatol. 2013;133(2):489-98. https://doi.org/10.1038/ jid.2012.330

PMid:22992806

21. $\mathrm{Xu} X, \mathrm{Fu} X Y$, Plate J, Chong AS. IFN-gamma induces cell growth inhibition by Fas-mediated apoptosis: Requirement of STAT1 protein for up-regulation of Fas and FasL expression. Cancer Res. 1998;58(13):2832-7.

PMid:9661898

22. Posadas SJ, Padial A, Torres MJ, Mayorga C, Leyva L, Sanchez E, et al. Delayed reactions to drugs show levels of perforin, granzyme B, and Fas-L to be related to disease severity. J Allergy Clin Immunol. 2002;109(1):155-61. https:// doi.org/10.1067/mai.2002.120563

PMid:11799383

23. Abe R, Yoshioka N, Murata J, Fujita Y, Shimizu H. Granulysin as a marker for early diagnosis of the Stevens-Johnson syndrome. Ann Intern Med. 2009;151(7):514-5. https://doi. org/10.7326/0003-4819-151-7-200910060-00016 PMid: 19805776

24. Schneck J, Fagot JP, Sekula P, Sassolas B, Roujeau JC, Mockenhaupt M. Effects of treatments on the mortality of Stevens-Johnson syndrome and toxic epidermal necrolysis: A retrospective study on patients included in the prospective EuroSCAR study. J Am Acad Dermatol. 2008;58(1):33-40. https://doi.org/10.1016/j.jaad.2007.08.039 PMid: 17919775

25. Conner CD, McKenzie E, Owen CE, Callen JP. The use of cyclosporine for Stevens-Johnson syndrome-toxic epidermal necrolysis spectrum at the University of Louisville: A case series and literature review. Dermatol Online J. 2018;24(1):qt6d56n4j8. PMid:29469760

26. Valeyrie-Allanore L, Wolkenstein $\mathrm{P}$, Brochard L, Ortonne N Maître $\mathrm{B}, \mathrm{Revuz} \mathrm{J}$, et al. Open trial of ciclosporin treatment for Stevens-Johnson syndrome and toxic epidermal necrolysis. $\mathrm{Br} J$ Dermatol. 2010;163(4):847-53. https://doi. 
org/10.1111/j.1365-2133.2010.09863.x PMid:20500799

27. Lee HY, Lim YL, Thirumoorthy T, Pang SM. The role of intravenous immunoglobulin in toxic epidermal necrolysis: A retrospective analysis of 64 patients managed in a specialized centre. $\mathrm{Br} J$ Dermatol. 2013;169(6):1304-9. https://doi. org/10.1111/bjd.12607

PMid:24007192

28. Paradisi A, Abeni D, Bergamo F, Ricci F, Didona D, Didona B. Etanercept therapy for toxic epidermal necrolysis. J Am Acad Dermatol. 2014;71(2):278-83. https://doi.org/10.1016/j. jaad.2014.04.044 PMid:24928706

29. Trent JT, Kirsner RS, Romanelli P, Kerdel FA. Analysis of intravenous immunoglobulin for the treatment of toxic epidermal necrolysis using SCORTEN: The University of Miami Experience. Arch Dermatol. 2003;139(1):39-43. https://doi. org/10.1001/archderm.139.1.39 PMid:12533162

30. Nesbitt LT. Minimizing complications from systemic glucocorticosteroid use. Dermatol Clin. 1995;13(4):925-39. PMid:8785896

31. Hirahara K, Kano $Y$, Sato $Y$, Horie C, Okazaki A, Ishida T, et al. Methylprednisolone pulse therapy for Stevens-Johnson syndrome/toxic epidermal necrolysis: Clinical evaluation and analysis of biomarkers. J Am Acad Dermatol. 2013;69(3):496-8. https://doi.org/10.1016/j.jaad.2013.04.007 PMid:23957982

32. Kardaun SH, Jonkman MF. Dexamethasone pulse therapy for Stevens-Johnson syndrome/toxic epidermal necrolysis. Acta Derm Venereol. 2007;87(2):144-8. https://doi. org/10.2340/00015555-0214

PMid: 17340021

33. Caproni M, Torchia D, Schincaglia E, Volpi W, Frezzolini A,
Schena D, et al. Expression of cytokines and chemokine receptors in the cutaneous lesions of erythema multiforme and Stevens-Johnson syndrome/toxic epidermal necrolysis. $\mathrm{Br} \mathrm{J}$ Dermatol. 2006;155(4):722-8. https://doi. org/10.1111/j.1365-2133.2006.07398.x

PMid: 16965421

34. Chawla-Sarkar M, Lindner DJ, Liu YF, Williams BR, Sen GC Silverman $\mathrm{RH}$, et al. Apoptosis and interferons: role of interferonstimulated genes as mediators of apoptosis. Apoptosis Int $\mathrm{J}$ Program Cell Death. 2003;8(3):237-49.

35. Tsujimoto M, Yip YK, Vilcek J. Interferon-gamma enhances expression of cellular receptors for tumor necrosis factor. J Immunol Baltim Md 1950. 1986;136(7):2441-4. PMid:3005410

36. Tamura T, Ishihara M, Lamphier MS, Tanaka N, Oishi I, Aizawa S, et al. DNA damage-induced apoptosis and Ice gene induction in mitogenically activated T lymphocytes require IRF-1. Leukemia. 1997;11(Suppl 3):439-40.

PMid:9209417

37. Schroder K, Hertzog PJ, Ravasi T, Hume DA. Interferon-gamma: An overview of signals, mechanisms and functions. J Leukoc Biol. 2004;75(2):163-89. https://doi.org/10.1189/jlb.0603252 PMid: 14525967

38. Steimle V, Siegrist CA, Mottet A, Lisowska-Grospierre B, Mach B. Regulation of MHC class II expression by interferongamma mediated by the transactivator gene CIITA. Science. 1994;265(5168):106-9. https://doi.org/10.1126/ science. 8016643 PMid:8016643

39. Früh $\mathrm{K}$, Yang $\mathrm{Y}$. Antigen presentation by MHC Class and its regulation by interferon gamma. Curr Opin Immunol. 1999;11(1):76-81. https://doi.org/10.1016/ s0952-7915(99)80014-4

PMid: 10047537 